\title{
Memoria celebrativa y memoria narrativa: los templos de la fama en los libros de caballerías ${ }^{1}$
}

\author{
Anna Bognolo \\ Universidad de Verona
}

Título: Memoria celebrativa y memoria narrativa: los templos de la fama en los libros de caballerías.

Resumen: Las representaciones de edificios, galerías, entornos pintados o enriquecidos con estatuas permiten reflexionar sobre un aspecto desatendido de los libros de caballerías españoles: los "templos de la memoria". Se ponen en relación ejemplos tomados de Amadis de Gaula y Sergas de Esplandián (1496-1510); Clarián de Landanis (1518); Lisuarte de Grecia, Florisel de Niquea, Amadis de Grecia (1514-1535); Silves de la Selva (1546); Olivante de Laura (1564); Espejo de principes (1587) y las continuaciones italianas de Mambrino Roseo: Palmerino (1560) y Sferamundi (1558-1565) con la tratadística y artes plásticas de la época: el Teatro de la Memoria de Giulio Camillo Delminio (1480-1544); el cenotafio del emperador Maximiliano en la Iglesia de Innsbruck (1553); el proyecto de Anton Francesco Doni para Arquà Petrarca (h. 1560); el Teatro Olimpico de Andrea Palladio en Vicenza (1579); el Museo de Paolo Giovio cerca del lago de Como (1543) y el salón de los Fasti del palacio Farnese de Caprarola (1559-1575).

Palabras clave: Libros de caballerías, Renacimiento, Artes plásticas, Teatro della Memoria, Giulio Camillo Delminio.

Fecha de recepción: 9/6/2020.

Fecha de aceptación: 18/7/2020.
Title: Celebrative Memory and Narrative Memory. Halls of Fame in Spanish Romances of Chivalry.

Abstract: The representations of buildings, galleries, environments painted or enriched with statues allow us to reflect on a neglected aspect of the Spanish books of chivalry: the "temples of memory". Examples taken from Amadis de Gaula and Sergas de Esplandián (1496-1510); Clarián de Landanis (1518); Lisuarte de Grecia, Florisel de Niquea, Amadis de Grecia (1514-1535); Silves de la Selva (1546); Olivante de Laura (1564); Espejo de principes (1587) and the Italian continuations of Mambrino Roseo: Palmerino (1560) and Sferamundi (1558-1565), are related with the treatise and plastic arts of that age: the Teatro della Memoria of Giulio Camillo Delminio (14801544), the cenotaph of the Emperor Maximilian in the Church of Innsbruck (1553), the project by Anton Francesco Doni for Arquà Petrarca (c. 1560), the Teatro Olimpico by Andrea Palladio in Vicenza (1579), the Museo of Paolo Giovio near Lake Como (1543), the Fasti hall of the Farnese palace in Caprarola (1559-1575).

Key words: Romances of Chivalry, Renaissance, Plastic Arts, Teatro della Memoria, Giulio Camillo Delminio.

Date of Receipt: 9/6/2020.

Date of Approval: 18/7/2020.

1 El presente trabajo se inscribe en el marco del "Progetto Mambrino", https://www. mambrino.it/it, y del "Progetto di eccellenza: Le Digital Humanities applicate alle 
En los libros de caballerías se incluyen una serie de aventuras ambientadas en espacios arquitectónicos — decorados con pinturas y estatuasque podríamos llamar templos de la memoria ${ }^{2}$. Se pueden reconstruir las raíces de estas formas en el pasado medieval, pero su presencia coincide con otro fenómeno plenamente renacentista: el triunfo de las "artes de la memoria”. Utilizadas desde la Antigüedad por los grandes oradores para pronunciar discursos elaborados sin el auxilio de la lectura, las mnemotécnicas eran un conjunto de métodos para memorizar informaciones, gracias a la posibilidad de recordar imágenes e historias asociadas a los objetos. Colocar mentalmente las nociones abstractas en lugares concretos y visualizarlas con los ojos de la imaginación, de manera plástica o pictórica, permitía retener conceptos abstractos de no fácil recuerdo.

Ya Cicerón aconsejaba utilizar espacios como los rincones de una casa para memorizar las ideas en los loci; en el Renacimiento se imaginaron grandiosos repertorios, como el Teatro de la Memoria de Giulio Camillo Delminio (1480-1544), con vistas a almacenar todo el saber humano mediante un sistema de asociaciones mnemónicas con imágenes ${ }^{3}$. Enton-

lingue e letterature straniere del Dipartimento de Lingue y letterature Straniere" de la Università de Verona, http://www.dlls.univr.it/?ent=progetto\&id=5327; y en el "Progetto PRIN 2017 Mapping Chivalry. Spanish Romances of chivalry from Renaissance to XXI century: a Digital approach" (2017JA5XAR), https://www. univr.it/it/iniziative/-/evento/8576?p_auth=ZcGFgkei.

2 Este trabajo prosigue una investigación que he profundizado en el tiempo, dedicándome sobre todo a pinturas murales (mientras que ahora pretendo centrarme en estatuas y personajes vivos): Anna Bognolo, "Il meraviglioso architettonico nel romanzo cavalleresco spagnolo", en Lettere e arti nel Rinascimento, Firenze, Cesati, 2000, pp. 207-219; "Il romanzo in una stanza. Le sale istoriate dello Sferamundi di Grecia”, en Con gracia y agudeza. Studi offerti a Giuseppina Ledda, ed. Antonina Paba, Roma, Aracne, 2007, pp. 85-104; "Los salones pintados de la Historia di Sferamundi di Grecia de Mambrino Roseo da Fabriano", en Il mondo cavalleresco tra immagine e testo, ed. Claudia Demattè, Trento, Università di Trento, 2010, pp. 85-113.

3 Para el 'Arte de la memoria' son fundamentales los trabajos de Frances A. Yates, El arte de la memoria, trad. Ignacio Gómez de Liaño, Madrid, Siruela, 2005; Mauricio Jalón, La plaza de las ciencias, Valladolid, Junta de Castilla y León, 1991; Paolo Rossi, Clavis universalis. Arti mnemoniche e logica combinatoria da Lullo a Liebniz, Bologna, Il Mulino, 1983. Además, Fernando Rodríguez de la Flor, Teatro de la memoria. Siete ensayos sobre mnemotecnía española de los siglos XVII y XVIII, Salamanca, Junta de Castilla y León, 1988; Aurora Egido, "El Arte de la Memoria y El Criticón”, en 
ces, las representaciones — recurrentes en los libros de caballerías- de edificios, galerías, entornos pintados o enriquecidos con estatuas, donde imágenes ejemplares de caballeros modernos conviven con los de la tradición antigua, permiten reflexionar sobre un aspecto desatendido de este género en España, en sintonía con varias tendencias del arte y de la literatura renacentista. Además, a la luz de las repeticiones del motivo se resalta su variedad, que muestra como los libros de caballerías están muy lejos de ser "todos una misma cosa" (DQ I, 48): cada época, cada libro nuevo, se esmera en ocurrencias que crecen sobre las experiencias anteriores, inventando situaciones inéditas e innovadoras.

Para empezar, quiero aducir dos ejemplos que, con su fuerza visual, nos llevan inmediatamente al núcleo del tema. Son diferentes, uno escultórico y otro literario, uno alemán y otro italiano, pero ambos tienen una fuerte vinculación con la tradición hispánica y son oportunos. Se trata del cenotafio del emperador Maximiliano en la Iglesia de la Corte de Innsbruck, en Austria, y de la aventura del Castello delle Memorie Antiche en la secuela italiana del Palmerín de Olivia (Venecia, 1560).

La Hofkirche ("Iglesia de la Corte") de Innsbruck fue construida en 1553 por el emperador Ferdinando I (1503-1564), hermano de Carlos V, en honor de su abuelo el emperador Maximiliano I (1459-1519) (Fig. 1). El cenotafio de mármol negro, que Maximiliano había planeado personalmente, ocupa el centro de la nave y su construcción duró más de ochenta años ${ }^{4}$. La parte más impresionante del monumento está constituida por las veintiocho estatuas de bronce de dos metros de altura que lo rodean, creadas entre 1502 y 1555: representan varios héroes, antepasados y parientes de Maximiliano. La lista comprende personajes de la historia reciente, como Juana de Castilla, Felipe el Hermoso, Fernando

Gracián y su época, Zaragoza, Institución Fernando el Católico, 1986, pp. 25-66; "La memoria y el arte narrativo del Persiles", Nueva Revista de Filología Hispánica, XXXVIII, 2 (1990), pp. 621-641; y Corrado Bologna, El teatro de la mente. De Giulio Camillo a Aby Warburg, trad. Helena Aguilà, Madrid, Siruela, 2017. Para el contexto italiano, véanse Lina Bolzoni y Pietro Corsi, La cultura della memoria, Bologna, Il Mulino, 1982; Lina Bolzoni, Le stanze della memoria, Torino, Einaudi, 1995.

4 La nueva iglesia construida entre 1549-1553 sirve únicamente como lugar del cenotafio; la tumba con los restos se encuentra en otra capilla en Wiener Neustadt. El sarcófago fue completado en 1572 y los adornos finales (el emperador arrodillado, las cuatro virtudes y la reja de hierro) fueron añadidos en 1584 . 
de Aragón, Margarita de Austria — duquesa de Saboya—, la emperatriz Blanca Maria Sforza y también personajes del pasado y de leyendas caballerescas como Arturo, rey de Gran Bretaña; Teodorico el Grande, rey de los Ostrogodos, o Godofredo de Bouillon. Las estatuas del rey Arturo (Fig. 2) y de Teodorico fueron diseñadas por Durero.

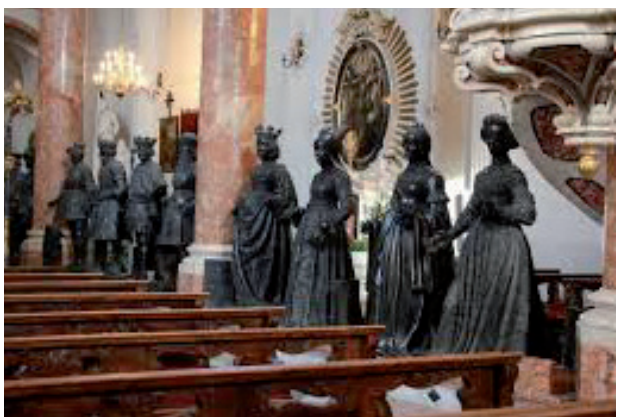

Fig. 1. Hofkirche Innsbruck

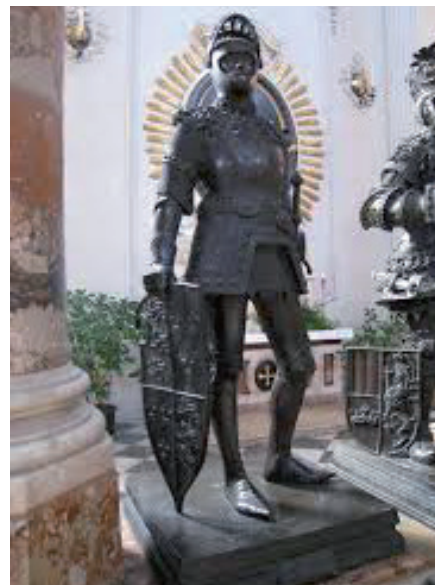

Fig. 2. Rey Arturo

El segundo ejemplo se encuentra al comienzo de Il Secondo libro di Palmerino di Oliva (Venezia, Tramezzino, 1560). La aventura empieza en la corte de Constantinopla; durante unos festejos, aparece un carro de fuego y una mensajera del mago Muzabelín anuncia la aventura del Castillo Maravilloso. Palmerín parte y accede al castillo. En el interior, en una plaza, se ven muchas estatuas de mármol de héroes y reyes del pasado:

Llegaron al gran palacio, ante el cual vieron una larga y espaciosa plaza en forma de teatro, alrededor de la cual estaban tantas estatuas de mármol como el circuito: con gran estupor vieron que eran retratos al natural de los famosos caballeros y de las bellas y famosas damas antiguas, las cuales eran mezcladas entre estos caballeros de varias vestimentas antiguas adornadas, según el tiempo en que existieron y según los países donde vivían, y de la misma manera los caballeros estaban armados, algunos cabalgando sus caballos y otros a pie, según su variado estilo de armarse. [...] Se veían las estatuas de caballeros y mujeres comenzando con aquellos y aquellas famosas 
que fueron en la época de la monarquía asiria, Júpiter, Belo, Nino y su hijo con su madre Semiramis, mitad armada y mitad en falda femenina. En la segunda monarquía de los Medios, Astiage y su hija con su esposo Cambises y Cyrus nacido de ellos.

Luego seguían los de la monarquía de los Persas, Cambises, Mergi, los Reyes Magos y sus siete asesinos; Darío primero con todos sus valientes descendientes hasta el último Darío, en cuyo tiempo Alejandro se hizo cargo de la monarquía de los Griegos; y se veían, con Alejandro, Ptolomeo, Antípatro, Antíoco, Casandro y todos los otros sátrapas de su familia, entre los cuales se dividió la monarquía. Luego seguían los valientes romanos armados según su costumbre, con todos los emperadores famosos hasta la época de Palmerino y después de la decadencia del imperio. Se veía el famoso rey Amadís de Gaula con todos sus gloriosos descendientes hasta Sferamundi, con todas las reinas, princesas y emperatrices descendientes de ellos. Y luego, al final de ese recorrido, se veían modelos de estatuas inacabadas [...], preparadas para estatuas del glorioso emperador Palmerino. [...] La doncella Iriolda venía de cada estatua contando la historia de todos estos ilustres caballeros y mujeres representados en estas estatuas, una por una (Palmerino II, c. 12-13, traducción mía) $)^{5}$.

5 "Giunsero al gran palagio, inanzi il quale viddero una lunga e spaziosa piazza in forma di teatro, all'intorno della quale erano poste statue di marmo tante quanto era il circuito: le quali con gran stupor mirando, viddero esser ritratti dal naturale dei famosi cavallieri e delle belle e famose donne antiche, le quali donne eran tramezzate tra quei cavallieri di vari antichi vestimenti adornate, secondo quel tempo nel quale furono e secondo i paesi nei quali erano vissute, e parimente i cavallieri erano armati, alcuni sopra dei loro cavalli e altri a piedi, secondo la loro variata foggia di armare. [...] Vedeansi le statue dei cavalieri e delle donne cominciando da quelli e quelle famose che furono nel tempo della Monarchia degli Assiri, Giove, Belo, Nino e il figliuolo con Semiramis sua madre, mezza armata e mezza in femminile gonna. Nella seconda Monarchia dei Medi, Astiage e la figliola col marito Cambise e Ciro nato di loro. Seguivano poi quei della Monarchia dei Persi, Cambise, Mergi, i Magi due fratelli e i sette uccisori loro; Dario primo con tutti i suoi valorosi descendenti fino all'ultimo Dario, nel cui tempo Alessandro sottentrò con la Monarchia dei Greci; e vedeansi, con Alessandro, Tolomeo, Antipatro, Antioco, Cassandro e tutti gli altri satrapi suoi criati, fra i quali fu la Monarchia divisa. Seguivano dopo i valorosi romani armati alla lor usanza, con tutti i famosi imperadori fino al tempo di Palmerino e dopo la declinazione dell'imperio. Vedeasi il famoso re Amadís di Gaula con tutti i suoi gloriosi descendenti fino a Sferamundi, con tutte le Reine e Principesse e Imperatrici discese da loro. Et poi nel fine di quel giro vedeasi modelli di statue non finite [...] 
Una plaza en forma de teatro, adornada con estatuas de damas y caballeros antiguos, que van desde los asirios a los romanos y a los mismos Palmerín y Amadís con su progenie, culmina con algunas estatuas inacabadas. Seguimos con la aventura: los protagonistas acceden a otra sala ornada con las estatuas de las damas de la compañía "di mirabilissimo ritratto e tale che paren vive". Superadas unas pruebas de valor masculino y de pureza femenina, al día siguiente la compañía entra en la Sala de las Virtudes, donde unas preciosas estatuas alegóricas (la Piedad, la Belleza, la Cortesía y la Inocencia para las damas; Néstor, Paris, Héctor, Aquiles, Sansón y Ulises para los caballeros) resultan ser autómatas que se ponen en movimiento para conceder coronas de gloria a los personajes que las merecen. Finalmente, la compañía entra en la Sala del Tesoro, donde, entre montañas de piedras preciosas y arcas rebosantes de medallas de emperadores romanos (Julio César, Augusto, Tiberio, Calígula, Nerva, Trajano, etc.), se guardan unas figuras doradas de astrólogos, patriarcas y profetas, con las esculturas de los siete planetas y de los cuatro elementos. En el centro triunfa la enorme estatua de la maga artífice del castillo, que en un arca de plata conserva el libro que profetiza la caída de Constantinopla. Cuando las aventuras tocan a su fin, y para maravilla de todos, las estatuas de Palmerín y de sus compañeros aparecen perfectamente acabadas. Desde aquel momento el castillo cambia de nombre y se conoce como el Castillo de las Memorias Antiguas (caps. 1-9).

Salvando las distancias, vemos que el cenotafio del emperador Maximiliano y el Castillo de las Memorias Antiguas comparten una misma pretensión. El solemne monumento sepulcral de Innsbruck se erige en un templo sagrado y conserva idealmente la imagen del emperador reinante sobre todos los caballeros y damas que le homenajean, antiguos y modernos, difuntos y vivos; quien entre a visitar la iglesia se sentirá rodeado de los personajes históricos allí representados. En ambos ejemplos, dentro de un digno edificio (iglesia, castillo), una procesión de héroes del presente, representados en obras figurativas, se coloca en línea de sucesión con unos héroes del pasado, de origen mítico e histórico, pagano y cristiano. El desarrollo temporal se extiende desde la más lejana antigüedad hasta hoy. De la misma manera que, en la tumba de Maximiliano, conviven la

apparecchiate per le statue del glorioso imperador Palmerino. [...] La donzella Iriolda veniva di ciascuna statua raccontando l'istoria di tutti questi cavalieri e donne illustre rappresentate in queste statue, ad una ad una" (Palmerino II, c. 12-13). 
estatua del rey Arturo y la de Juana la Loca, que murió en 1555, en la novela italiana, la noble ascendencia imaginaria se remonta por un lado a tiempos tan lejanos como los de los reyes asirios, y llega por el otro hasta al tiempo actual de los más recientes Amadises y Palmerines.

Notemos los detalles: en el ejemplo italiano, la plaza de las estatuas de mármol es "in forma di teatro", palabra significativa en este contexto. En ambos ejemplos, las estatuas están vestidas y adornadas según "la lor variata foggia”, de épocas que pueden ser muy diferentes, como vemos en el cenotafio de Innsbruck. En el ejemplo del libro de caballerías italiano, una maga conduce al grupo de damas y caballeros en una visita guiada al teatro para ver "cada estatua contando la historia de todos estos ilustres caballeros y mujeres representados en estas estatuas, una por una”. Al final aparecen unas imágenes apenas esbozadas ("Y luego, al final de ese recorrido, se veían modelos de estatuas inacabadas [...] preparadas para estatuas del glorioso emperador Palmerino") y en la sala contigua se retrata a algunos participantes de la misma compañía, sorprendentemente reflejados en un doble. Algunas de las estatuas son autómatas que de repente se ponen en movimiento y actúan para coronar a los héroes ${ }^{6}$. Mientras que el cenotafio del emperador Maximiliano es fijo, en una novela se puede imaginar el movimiento, tanto que el recorrido turístico ceremonial es una aventura que culmina en una prueba de valores caballerescos para glorificar a los héroes: entonces el castillo se transforma y asume un nuevo nombre, de "Castello Meraviglioso Ritrovato" pasará a llamarse "Castello delle Memorie Antiche". La señal de conclusión de la aventura consiste en que las estatuas apenas esbozadas ahora están terminadas, justamente las de los protagonistas.

El motivo narrativo del "templo de la fama" presente en el ejemplo italiano es frecuente en los libros de caballerías ibéricos. Se podrían aducir varios ejemplos, como los conocidos de Feliciano de Silva. Sin embargo, no todos son uno: las variantes del motivo son significativas. A veces la aventura se atribuye a un personaje que pertenece a la diégesis; otras se pone a nivel extradiegético como experiencia del autor en un sueño o visión.

6 Habría que comentar la presencia de las medallas de los emperadores romanos, síntoma de una pasión nueva por la numismática. Los saberes arqueológicos y anticuarios que se estrenaban justamente entonces en Roma eran familiares a Roseo, que estaba ligado al ambiente de la librería Tramezzino, lugar de tertulia con personajes como Pirro Ligorio, donde se publicaron varios tratados sobre Roma antigua. 
Siempre se ambienta en un espacio arquitectónico rico y decorado: pero puede ser un palacio o también una cueva subterránea. La écfrasis puede retratar representaciones figurativas como obras de pintura, tapices, vidrieras o esculturas; en algunas ocasiones se refiere a personajes vivos, despiertos o encantados. Los héroes representados pueden ser personajes de la misma obra o del mismo ciclo al que la obra pertenece, o en otros casos el autor puede evocar otras historias, leyendas o ciclos anteriores o rivales.

A manera de muestra propongo la siguiente tabla, con el propósito de fijarme en algunos de los ejemplos citados.

\begin{tabular}{|c|c|c|c|c|c|c|c|}
\hline Fecha y Autor & OBRA & $\begin{array}{l}\text { NOMBRE DE LA } \\
\text { AVENTURA }\end{array}$ & $\begin{array}{l}\text { AVENTURA DEL } \\
\text { PERSONAJE / } \\
\text { SuEŃo DEL AUTOR }\end{array}$ & $\begin{array}{l}\text { Castillo } \\
\text { Cripta }\end{array}$ & $\begin{array}{l}\text { Pintura / } \\
\text { TAPICES / } \\
\text { Vidrieras / } \\
\text { Esculturas }\end{array}$ & ENCANTAMIENTO & HÉroes REPRESENTADOS \\
\hline $\begin{array}{c}\text { 1496-1510 } \\
\text { Rodríguez } \\
\text { de Montalvo }\end{array}$ & $\begin{array}{l}\text { Amadis de } \\
\text { Gaula y Sergas de } \\
\text { Esplandián }\end{array}$ & $\begin{array}{c}\text { Encantamiento } \\
\text { Ínsula Firme }\end{array}$ & $\begin{array}{l}\text { Aventura y } \\
\text { Sueńo }\end{array}$ & $\begin{array}{l}\text { Castillo y } \\
\text { Cripta }\end{array}$ & & $\begin{array}{l}\text { Personajes } \\
\text { encantados y } \\
\text { vivos }\end{array}$ & $\begin{array}{c}\text { Personajes del ciclo } \\
\text { de Amadís }\end{array}$ \\
\hline $\begin{array}{c}1518 \\
\text { G. Velázquez } \\
\text { de Castillo }\end{array}$ & $\begin{array}{l}\text { Clarián de } \\
\text { Landanís }\end{array}$ & $\begin{array}{l}\text { Cueva de } \\
\text { Hércules }\end{array}$ & $\begin{array}{l}\text { Aventura del } \\
\text { personaje }\end{array}$ & $\begin{array}{c}\text { Cueva y } \\
\text { Cripta }\end{array}$ & Estatuas & & $\begin{array}{l}\text { Héroes bíblicos y clásicos: } \\
\text { Sansón, Judas Macabeo, } \\
\text { Hércules, Héctor, Tristán e } \\
\text { Iseo, Lanzarote y Ginebra } \\
\text { Personajes del ciclo }\end{array}$ \\
\hline $\begin{array}{c}1514 \\
\text { Feliciano } \\
\text { de Silva }\end{array}$ & $\begin{array}{l}\text { Lisuarte de } \\
\quad \text { Grecia }\end{array}$ & $\begin{array}{l}\text { Castillo de } \\
\text { Fenusa }\end{array}$ & Aventura & Castillo & Tapices & & $\begin{array}{c}\text { Personajes del ciclo } \\
\text { de Amadís }\end{array}$ \\
\hline \multirow[t]{2}{*}{1530} & Amadis de Grecia & $\begin{array}{l}\text { Castillo de las } \\
\text { siete torres }\end{array}$ & Aventura & Castillo & $\begin{array}{c}\text { Pintura y } \\
\text { estatuas }\end{array}$ & & $\begin{array}{c}\text { Personajes del ciclo } \\
\text { de Amadís }\end{array}$ \\
\hline & Amadis de Grecia & $\begin{array}{l}\text { Torre del } \\
\text { universo }\end{array}$ & Aventura & Castillo & Pinturas & $\begin{array}{l}\text { Personajes en- } \\
\text { cantados vivos }\end{array}$ & $\begin{array}{c}\text { Personajes del ciclo } \\
\text { de Amadís }\end{array}$ \\
\hline $\begin{array}{l}1535 \\
\text { Feliciano } \\
\text { de Silva }\end{array}$ & $\begin{array}{c}\text { Florisel de } \\
\text { Niquea (III) }\end{array}$ & Alto Roquedo & & Castillo & $\begin{array}{c}\text { Vidrieras y } \\
\text { estatuas }\end{array}$ & & $\begin{array}{l}\text { Personajes del ciclo y la } \\
\text { antigüedad Policena y } \\
\text { Helena / Rey Arturo }\end{array}$ \\
\hline $\begin{array}{c}1546 \\
\text { Pedro de Luján }\end{array}$ & Silves de la Selva & $\begin{array}{l}\text { Cámara sepulcro } \\
\text { de Amadís }\end{array}$ & Sueńo del autor & Castillo & Vidrieras & & $\begin{array}{c}\text { Personajes del ciclo } \\
\text { de Amadís }\end{array}$ \\
\hline $\begin{array}{l}1564 \\
\text { Antonio de } \\
\text { Torquemada }\end{array}$ & $\begin{array}{l}\text { Olivante } \\
\text { de Laura }\end{array}$ & $\begin{array}{c}\text { Casas y jardines } \\
\text { de la sabia } \\
\text { Ypermea }\end{array}$ & Sueño & $\begin{array}{l}\text { Cueva y } \\
\text { Castillo }\end{array}$ & & $\begin{array}{l}\text { Personajes en- } \\
\text { cantados vivos }\end{array}$ & $\begin{array}{l}\text { Héroes bíblicos, clásicos y } \\
\text { cristianos: Héctor, Aquiles, } \\
\text { Alejandro Magno, Julio } \\
\text { César, rey Arturo, Carlo- } \\
\text { magno y los Doce pares, } \\
\text { Godofredo de Bullón. } \\
\text { Personajes del ciclo de } \\
\text { Amadís y Palmerín y al } \\
\text { final Olivante y Lucenda }\end{array}$ \\
\hline $\begin{array}{l}1558-1565 \\
\text { Mambrino } \\
\text { Roseo }\end{array}$ & $\begin{array}{l}\text { Sferamundi } \\
\text { di Grecia }\end{array}$ & $\begin{array}{l}\text { Sala del sole } \\
\text { e della luna }\end{array}$ & Aventura & Castillo & Pintura & & $\begin{array}{c}\text { Personajes del ciclo } \\
\text { de Amadís }\end{array}$ \\
\hline $\begin{array}{c}1560 \\
\text { Mambrino } \\
\text { Roseo }\end{array}$ & $\begin{array}{l}\text { Palmerino } \\
\text { di Oliva II }\end{array}$ & $\begin{array}{l}\text { Castello } \\
\text { delle Memorie } \\
\text { antiche }\end{array}$ & Aventura & Castillo & $\begin{array}{c}\text { Esculturas y } \\
\text { autómatas }\end{array}$ & & $\begin{array}{l}\text { Personajes del ciclo de } \\
\text { Amadís y Palmerín, cabal- } \\
\text { leros y doncellas, maga, } \\
\text { antiguos héroes, astrólogos, } \\
\text { patriarcas y profetas }\end{array}$ \\
\hline $\begin{array}{c}1587 \\
\text { Marcos } \\
\text { Martínez }\end{array}$ & $\begin{array}{c}\text { Espejo de } \\
\text { príncipes III }\end{array}$ & $\begin{array}{l}\text { Cueva de } \\
\text { Anglante }\end{array}$ & Sueńo & Castillo & \begin{tabular}{l|} 
Retratos y \\
esculturas
\end{tabular} & $\begin{array}{l}\text { Personajes en- } \\
\text { cantados vivos }\end{array}$ & $\begin{array}{l}\text { Los nueve de la Fama, los } \\
\text { doce pares, personajes del } \\
\text { ciclo de Amadís, Palmerín, } \\
\text { muchos otros. }\end{array}$ \\
\hline
\end{tabular}

Fig. 3. Tabla 
Entre los infinitos ejemplos posibles, hemos querido recoger algunos que permiten un recorrido histórico desde los primeros a los últimos libros de caballerías, a través de diferentes variantes que comentaremos a continuación. Pero antes hay que detenerse un momento en los antecedentes del motivo objeto de nuestro análisis.

Las raíces románicas de la gran sala pintada o decorada con estatuas de personajes novelescos o mitológicos se remontan a versiones tan antiguas como la sala del palacio de Morgana en el Lanzarote de la Vulgata (siglo XIII), donde el protagonista, prisionero, pinta la historia de sus amores con Ginebra; o como los pabellones historiados del Libro de Alexandre, o la "Halle aux Images" del Tristan de Thomas". En las innumerables variantes del tópico confluyen matrices heterogéneas, grecolatinas y medievales, que alimentan la tradición literaria humanística y renacentista de los mausoleos de glorias guerreras, de las galerías y los triunfos de figuras ejemplares, de las criptas y los monumentos sepulcrales, de los palacios y los templos subterráneos; cadena que no se interrumpe en el siglo XVI, sino que se renueva con sus herederos platerescos, decorados de murales, vidrieras, galerías de retratos, estatuas, autómatas, procesiones y tableaux vivants. Las recurrencias del motivo encarnan asimismo una tendencia alegórica de larga duración que se extiende desde la Edad Media y el Humanismo (piénsese en el Laberinto de Fortuna de Juan de Mena) hasta la ritualidad de los templos de la novela pastoril (el libro IV de la Diana), para llegar al lenguaje emblemático de las visiones mnemotécnicas de las arquitecturas y de los festejos del Renacimiento y del Barroco ${ }^{8}$.

7 Véase Juan Manuel Cacho Blecua, "La tienda en el Libro de Alexandre", en Actas del Congreso Internacional sobre la lengua y la literatura en tiempos de Alfonso X, eds. Fernando Carmona Fernández y Francisco José Flores Arroyuelo, Murcia, Universidad de Murcia, 1985, pp. 109-134. Para la Halle aux Images del Tristan de Thomas; cfr. Aurelio Roncaglia, "La statua di Isotta”, Cultura Neolatina, 31 (1971), pp. 41-67; y, sobre todo, el reciente estudio de Maria Luisa Meneghetti, Storie al muro: temi e personaggi della letteratura profana nell'arte medievale, Torino, Einaudi, 2015.

8 El itinerario lo reconstruye María Rosa Lida, "La visión del trasmundo en las literaturas hispánicas", en Howard Rollin Patch, El otro mundo en la literatura medieval (1950), México, FCE, 1983, pp. 369-449. Para una idea general sobre el Renacimiento y Barroco véase al menos Jorge Checa, Gracián y la imaginación arquitectónica: espacio y alegoría de la Edad Media al Barroco, Potomac, Scripta humanistica, 1986. Cfr. también Jorge Montemayor, La Diana, ed. Juan Montero, Barcelona, Crítica, 
En los libros de caballerías la atención se centra sobre todo en historias de amor y de gloria guerrera, y el motivo se concreta en galerías celebrativas de amantes y caballeros ejemplares, unas Casas de la Fama que se asemejan también a aquellas reseñas humanísticas de varones ilustres o famosas mujeres víctimas de amores desdichados (desde las Heroidas hasta Boccaccio, Rodríguez de Padrón o Valera), que pasan revista a los héroes, por medio de écfrasis, para la conservación de la memoria futura ${ }^{9}$. En este

1996, pp. 165-213 y 386 y ss. Las écfrasis de la Diana quizás vengan de estímulos italianos, como insinúa Maxime Chevalier, L'Arioste en Espagne (1530-1650). Recherches sur l'influence du "Roland Furieux", Bordeaux, Institut d'Etudes Ibériques et Ibéro-Américaines, 1966, pp. 276-77. Para los sueños alegóricos, cfr. Chandler Rathfon Post, Medieval Spanish Allegory, Hildesheim-New York, Georg Olms, 1971, y Barbara E. Kurtz, "Diego de San Pedro's Cárcel de Amor, and the Tradition of the Allegorical Edifice”, Journal of Hispanic Philology, 8 (1984), pp. 123-138. Insistir en la importancia de la alegoría en el arte y en la fiesta del Renacimiento y del Barroco sería el cuento de nunca acabar. Véase Antonio Bonet Correa, Fiesta, poder y arquitectura, Madrid, Akal, 1990; Maurizio Fagiolo Dell'Arco y Silvia Carandini, L'effimero barocco. Strutture della Festa nella Roma barocca, Roma, Bulzoni, 1977-1978, 2 vols.; Fernando Rodríguez de la Flor, Política y fiesta en el Barroco, Salamanca, Universidad de Salamanca, 1994. Para la emblemática, Giuseppina Ledda, La parola e l'immagine: strategie della persuasione religiosa nella Spagna secentesca, Pisa, ETS, 2003; Fernando Rodríguez de la Flor, Emblemas: lectura de la imagen simbólica, Madrid, 1995. También los trabajos del "Seminario interdisciplinar para el estudio de la Literatura áurea española” (SIELAE) de Sagrario López Poza en la Universidade da Coruña, https:// www.bidiso.es/index.htm. Un desarrollo hipertrófico de la alegoría, ambientada en espacios cada vez más complicados y preciosos, se encuentra también en los libros de caballerías a lo divino, como La Peregrinación de la vida del hombre o Caballero del Sol, de Pedro Hernández de Villaumbrales (1552), ed. H. Salvador Martínez, Madrid, 1986 (la Séptima morada muestra la écfrasis de los reyes de España); cfr. el estudio de Jorge Checa, "El caballero del sol de Hernández de Villaumbrales y el género de las novelas de caballerías a lo divino”, Crítica Hispánica, X (1988), pp. 49-66.

9 Sobre el topos de la Casa de la Fama véase María Rosa Lida, op. cit. Cfr. también Gustavo Correa, "El templo de Diana en la novela de Jorge de Montemayor", Thesaurus, XVI (1961), pp. 59-76; y Frederick A. De Armas, "Caves of Fame and Wisdom in the Spanish Pastoral Novel", Studies in Philology, 3 (1985), pp. 332-358. Enrique Moreno Báez, en la introducción a su edición de Jorge de Montemayor, Los siete libros de la Diana, Madrid, RAE, 1955, pp. XXIX-XXX, nota 39, pone en relación el templo de Diana con la tradición caballeresca y se refiere a los materiales de que se construyen los palacios del Morgante, del Orlando Innamorato y del Orlando Furioso. También hay rica bibliografía en la ed. cit. de La Diana de Juan Montero, 
contexto, el caso particular de las criptas se conecta con el itinerario del motivo del palacio subterráneo, conmemorativo o profético, arraigado en la tradición románica (la historia de Merlín enterrado en una cueva de cristal y la de Febus el Fuerte en el Roman de Palamedés), cuya vitalidad en España, a través de las versiones del Baladro del Sabio Merlín y las tumbas de los desafortunados amantes en la novela sentimental, dura hasta los siglos XV y XVI ${ }^{10}$.

En los libros de caballerías, aventuras como la irrupción en un castillo encantado o la exploración de una cueva subterránea representan a menudo las pruebas supremas que confirman de manera elocuente y definitiva la superioridad del caballero elegido. Tiene sentido distinguir entre castillo y cueva ${ }^{11}$, topología que implica la simbología de los itinerarios ascensionales o infernales, pero ambos conforman centros de reunión o de pasaje que asumen un fuerte peso semántico, porque obstaculizan a los héroes o los proyectan hacia su nuevo destino.

Son también importantes núcleos ideológicos y didácticos, ocasiones para el despliegue visual y simbólico de los más altos valores cortesanos. En el camino del caballero suele haber señas proféticas o conmemorativas como epígrafes, padrones, monumentos. La habitación más interior, la más espléndidamente decorada, actúa como un "sagrario", un lugar de máxima densidad misteriosa, en el que se accede a revelaciones, se cumplen desencantamientos, se obtienen tesoros o armas mágicas predesti-

pp. 386 y ss. Sobre las galerías de mujeres virtuosas me limito a señalar el estudio y edición de Federica Accorsi de Diego de Valera, Defensa de virtuosas mujeres, Pisa, ETS, 2009, que reúne la bibliografía.

10 Maria Luisa Meneghetti, "Palazzi sotterranei, amori proibiti", Medioevo romanzo, XII (1987), pp. 443-56; sobre Juan Rodríguez de Padrón, cfr. María Rosa Lida, Estudios sobre la Literatura Española del Siglo XV, Madrid, José Porrúa Turanzas, 1978, pp. 106-116. Véase también Lilia Orduna Ferrario, "La función de la ekphrasis en los relatos caballerescos", Letras, 40-41 (2000), pp.107-114.

11 Fundamental es el estudio de Juan Manuel Cacho Blecua, "La cueva en los libros de caballerías: la experiencia de los límites", en Descensus ad inferos. La aventura de Ultratumba de los héroes (de Homero a Goethe), ed. Pedro Manuel Piñero Ramírez, Sevilla, Universidad de Sevilla, 1995, pp. 99-127. Véase también Helena Percas de Ponseti, "La Cueva de Montesinos" en El "Quijote" de Cervantes, ed. George Haley, Madrid, Taurus, 1980, pp. 142-174. 
nadas $^{12}$. En muchos casos, en la parte interior del castillo o del jardín, o en la más profunda de la cueva, hay una capilla funeraria con un monumento sepulcral, donde la memoria se conserva por medio de estatuas en tronos, ciclos de frescos en las paredes o a través de la inmortalidad adquirida gracias a un encantamiento. El salón del castillo o la cripta de los héroes se convierte entonces en un espacio fuera de la historia, un lugar de protección contra la muerte, como sigue siendo el caso de la parodia cervantina de la Cueva de Montesinos ${ }^{13}$.

En la épica culta, estas galerías de personajes famosos se prestan a celebraciones dinásticas (como, por ejemplo, en el III canto del Orlando Furioso ${ }^{14}$; sin embargo, en los libros de caballerías los mausoleos donde se inmortaliza a los héroes no suelen referirse a los mecenas, sino que crean unas genealogías caballerescas pseudo-históricas: por ejemplo, los llamados "nueve de la Fama", el panteón absoluto y patrimonio común de la caballería, que representa una especie de translatio militiae y crea un compañerismo entre héroes bíblicos y clásicos y los de la novela caballeresca medieval ${ }^{15}$.

12 Véase Stefano Neri, L'eroe alla prova. Architetture meravigliose nel romanzo cavalleresco spagnolo del Cinquecento, Pisa, ETS, 2007.

13 Aurora Egido, Cervantes y las puertas del sueño. Estudios sobre "La Galatea", el "Quijote" y el "Persiles", Barcelona, PPU, 1994, pp. 137-78 y 179-122.

14 En los poemas italianos las écfrasis tienen importancia en la estructura narrativa y una fuerte carga ideológica, alusiva a la realidad de las cortes que están en la base del encargo, con un salto a lo extraliterario, porque redundan en un panegírico del destinatario. Suelen ser dinásticas y atribuyen una genealogía ennoblecedora a la familia de los mecenas, presuponiendo legendarios héroes epónimos como antecesores del príncipe. De esta manera, como ocurre en el Orlando Furioso, el poema se ofrece como glorificación de la familia y la écfrasis representa el momento de máxima concentración mítica, profética y encomiástica. Guido Baldassarri, "Ut poesis pictura. Cicli figurativi nei poemi epici e cavallereschi", en La corte e lo spazio: Ferrara estense, eds. Giuseppe Papagno y Amedeo Quondam, Roma, Bulzoni, 1982, pp. 605-635. Riccardo Bruscagli, "L'ecfrasi dinastica nel poema eroico del Rinascimento", en Ecfrasi. Modelli ed esempi tra Medioevo e Rinascimento, eds. Gianni Venturi e Monica Farnetti, Roma, Bulzoni, 2004, pp. 269-292. Véase también la interesante perspectiva de Eleonora Stoppino, Genealogies of Fiction: Women Warriors and the Dynastic Imagination in the "Orlando furioso", Nueva York, Fordham University Press, 2012.

15 Los nueve de la Fama suelen ser tres héroes bíblicos, tres clásicos y tres medievales o "modernos". El espectro de posibilidades comprende a David, Sansón, Jasón, Eneas, Hércules, Héctor, Aquiles, Alejandro, César, Lanzarote y otros héroes de tradición caballeresca románica. 
Hemos elegido ejemplos de varias fechas para subrayar las posibilidades de rejuvenecimiento del tópico, que experimenta variantes diferentes, se enriquece, se hace dinámico e intenta sorprender a los lectores. La aventura de la Cueva de Hércules en el Clarián de Landanís puede mostrar un ejemplo ya muy rico y complicado en data temprana (1518), pues se desarrolla en un laberinto de espacios subterráneos que termina en una cripta de héroes a los cuales se agregará el caballero protagonista.

Seguimos por un momento el camino de Clarián: desciende a la oscuridad por unos escalones tallados en la roca, baja por una vertiginosa espiral y toca el fondo del abismo en un patio de piedra negra, donde una inscripción en letras de oro sostenida por dos leones rampantes anuncia la fama imperecedera del caballero que pasará las pruebas. Clarián derrota a dos dragones y se topa con otro epígrafe inscrito en un padrón de marfil. Pasando por una habitación cubierta por una cúpula negra, habitada por un monstruo, llega a una cámara labrada con ventanas que dan a un exuberante jardín. En este entorno hay una sala maravillosa: el suelo, hecho de una sola hoja de rubí, es sostenido por cuatro leones de mármol coronados de oro, las paredes de cristal están coloreadas y brillan como espejos, el techo es dorado, las puertas son de oro y piedras preciosas y alrededor del edificio hay treinta árboles frutales tallados en oro. En el interior, en ricos tronos, hay estatuas de caballeros y mujeres nobles: héroes bíblicos y clásicos y parejas de amantes famosos (Tristán e Iseo, Lanzarote y Ginebra). Alrededor de la mesa de esmeraldas, a su vez apoyada en estatuas doradas, hay otras estatuas de guerreros famosos: Sansón, Judas Macabeo, Hércules y Héctor. Cuando Clarián entra en esta sala, su victoria provoca el colapso de toda la parte externa de la cueva, dejando descubierto el maravilloso edificio: en este momento en el panteón de héroes también aparece su misma estatua y una inscripción en letras negras en un áureo padrón celebra su gloria. Pero eso no es todo: en el camino de regreso encuentra ya talladas todas las aventuras que ha realizado en una piedra blanca sostenida por dos grifos de mármol, mientras que la estatua de un viejo venerable lleva su misma crónica recién escrita en letras de oro (p. 438) ${ }^{16}$. En este caso las imágenes asocian héroes bíblicos, clásicos y

16 Gabriel Velázquez del Castillo, Clarián de Landanis, ed. Gunnar Anderson, Newark, Juan de la Cuesta, 1995, pp. 413 y ss. La descripción de la Casa de Hércules en las letras hispánicas es una tradición bien definida, presente en la leyenda del rey Rodrigo, 
artúricos. La aventura hace cambiar el edificio y el caballero protagonista resulta ser el último eslabón de una cadena de glorias pasadas, inmortalizado en tres formas diferentes: en representación plástica (estatua y bajorrelieve) y en el libro escrito.

Lo que se ha visto en el Clarián tiene un precedente en el Amadís de Gaula. El palacio de la Ínsula Firme es el primer conjunto de edificios maravillosos en un libro de caballerías, cuya complejidad es quizás el resultado de superposiciones sucesivas; su mutación mágica hace que se proponga como la matriz de ambas formas: el castillo y la cueva.

Las magníficas residencias de la Ínsula Firme construidas por el mago Apolidón comprenden, con el "Arco de los leales amadores" y la "Cámara defendida", el edificio de la Torre de la Huerta, rodeado por un pórtico de mármoles exóticos y un jardín con cuatro fuentes zoomorfas. En la continuación, la Sergas de Esplandián, la maga Urganda la Desconocida, después de haber acomodado a los héroes principales, unos en la Cámara defendida, otros en el palacio al lado del Arco, y haberlos profundamente encantado, sube a la Torre de la Huerta y pronuncia las fórmulas mágicas que elevan en el aire toda la isla y luego la hunden en el abismo. Las maravillosas arquitecturas, perfectamente intactas, ahora se encuentran bajo tierra, y allí las descubrirá el autor Montalvo después de un tremebundo viaje subterráneo. Desde el fondo de un pozo, después de pasar por una boca infernal y continuar bajando durante dos horas, inesperadamente volverá a ver el cielo resurgiendo en la ínsula Firme, donde, guiado por Urganda, visitará la Torre y la Cámara defendida, pudiendo contemplar con facilidad a todos los personajes encantados e imperecederos. Al final de su pequeño viaje dantesco, la maga entregará al autor el libro de las empresas de Esplandián, que, después del debido trabajo de traducción y transcripción, es justamente el que estamos leyendo.

quien, al romper las prohibiciones y entrar al palacio de Hércules para apoderarse de un tesoro legendario, en una arquitectura admirable habría encontrado las inscripciones proféticas que anunciaban su ruina y la invasión musulmana de la península. La leyenda es transmitida por romances, cfr. Romancero, ed. Giuseppe Di Stefano, Madrid, Taurus, 1993, p. 315; y también en la Cronica sarracina de Pedro del Corral (1430). Véase Textos medievales de caballerías, ed. José María Viña Liste, Madrid, Cátedra, 1993, pp. 564 y ss. La visita a "los palacios de Hércules" se documenta también en la Lamentación/Sueño al final de la primera parte del Amadís de Grecia. Cfr. Juan Manuel Cacho Blecua, "La cueva en los libros de caballerías", p. 107. 
En el paso del Amadis a las Sergas asistimos entonces a una metamorfosis en la que el castillo, con todo su patrimonio de encantamientos, se invierte como un guante y se transforma en una cueva. La transformación de un palacio en una cripta subterránea muestra cómo los edificios de Ínsula Firme pueden estar en el origen de las dos formas que se han identificado anteriormente.

El Olivante de Laura de Antonio de Torquemada (1564) es de fecha posterior, coetáneo de los monumentos funerarios de Innsbruck y del Palmerino italiano, y ofrece un ejemplo de complicación ulterior del motivo, donde los héroes son numerosos y activos, no encantados ni transformados en estatuas, sino vivientes. Como en las Sergas, el que visita a los héroes antiguos es el propio autor, capturado en un sueño y guiado por la maga Ypermea. Entrando en el jardín por medio de un viaje fantástico a través de una cueva, el autor asiste a un torneo donde los caballeros famosos, de Sansón a Héctor, de Alejandro a Lanzarote, a Amadís y sus innumerables nietos, miden sus fuerzas ante los ojos satisfechos de la maga espectadora, que declara explícitamente haber preservado de la muerte a los héroes para su propio deleite. Los héroes entonces no están esculpidos, ni pintados o tejidos en un tapiz, sino vivos y en movimiento, y son descritos con una modalidad de écfrasis en evidentia dinámica durante un combate detallado ${ }^{17}$; en realidad, esto no sorprende si se considera cuán poca distancia hay, en la tradición, entre los príncipes encantados fijos en sus tronos y sus estatuas funerarias, como hemos visto en las Sergas y en el monumento de Innsbruck: respectivamente, una expresión literal y figurada de su inmortalidad.

El tema puede alcanzar una complejidad y un enriquecimiento todavía mayores, recogiendo un verdadero muestrario de varios ciclos, como ocurre en un libro de caballerías tardío, la Tercera parte del Espejo de Príncipes y Cavalleros (1587). En el palacio del sabio Anglante, el autor descubre una análoga galería de personajes y tiene que enfrentarse nada menos que a los nueve de la Fama vivos y coleando: el rey Arturo, Héctor, Alejandro,

17 La narración de un combate es una modalidad de la descriptio, cfr. María Luisa López Grigera, "Sobre el realismo literario del Siglo de Oro", en La retórica en la España del Siglo de Oro, Salamanca, Universidad de Salamanca, 1994, pp. 133-139 (135); Mario Pozzi, "Teoria e fenomenologia della descriptio nel Cinquecento italiano”, Giornale storico della Letteratura Italiana, 157 (1980), pp. 161-179 (p. 176). 
Carlomagno, Godofredo de Bullón; a continuación, en otra sala visita una galería de retratos de los reyes de España y de Francia y puede admirar el bullicio de las grandes ciudades del mundo en una esfera mágica. En otra parte visita un palacio con un panteón de héroes en el que contempla las estatuas de los doce pares con sus consortes, los descendientes de Amadís y de Palmerín, hasta llegar a Cristalián, Olivante, Belianís, Felixmarte y, por último, a los héroes de su mismo ciclo, Trebacio y Alfebo.

En otros casos, como en la Sala del Sol y de la Luna del Sferamundi (III, caps. 132-136), el interés reside en el despliegue del entero contenido del ciclo en un orden sistemático completo, un microcosmos novelesco que, en una única sala pintada, reúne todos los libros y aventuras del Amadis ${ }^{18}$. Entonces, lo que se presenta como una galería de héroes ficticios puede verse como la enunciación de una verdadera dinastía literaria, un homenaje a los padres de la ficción anterior y a la continuidad del género. Enumerando los precursores de su héroe de papel en un templo de falsos héroes, el autor reconstruye las líneas de la trama de todo el ciclo, hace a

18 Anna Bognolo, Los salones pintados, op. cit. A la derecha (en la "facciata a man dritta"), en tres fajas horizontales, yendo de arriba abajo, se ven respectivamente las historias de Amadis (libros I-IV), las de las Sergas de Esplandián (libro V) y las del Lisuarte de Grecia de Feliciano de Silva (libro VII). A la izquierda ("dalla man stanca"), los acontecimientos del Amadís de Grecia (libro IX), del Florisel de Niquea (libro X) y, por último, sin terminar, los del Rogel de Grecia (libro XI). En las paredes frontales, también sin acabar, se encuentran las historias de Don Silves de la Selva (libro XII) y de Sferamundi (libro XIII). Como subrayaba Claudia Demattè, la écfrasis no se realiza tanto con la descripción de la pared pintada, sino que está focalizada a través de los ojos de los personajes maravillados. Véanse Claudia Demattè, "Memoria ex visu y empresas caballerescas: de la Gran conquista de Ultramar a los libros de caballerías con una referencia al Persiles", en Letteratura della memoria. Atti del XXI Convegno dell'Associazione degli Ispanisti Italiani, eds. Domenico Antonio Cusato, Loretta Frattale, Gabriele Morelli, Pietro Taravacci y Belén Tejerina, Roma, Bulzoni, 2004, pp. 99-118; Claudia Demattè, "Memoria ex visu y empresas caballerescas (II): de los libros de caballerías al Persiles sin olvidarse del Quijote", en Peregrinamente peregrinos. Actas del V Congreso Internacional de la Asociación de Cervantistas, ed. Alicia Villar Lecumberri, Alcalá de Henares, Asociación de Cervantistas, 2004, pp. 349-331; y Claudia Demattè, "La mise en abyme en los libros de caballerías hispánicos", en Actas del IX Congreso Internacional de la Asociación Hispánica de Literatura Medieval (A Coruña, 18-22 de septiembre de 2001), eds. Carmen Parrilla y Mercedes Pampón, A Coruña, Universidade da Coruña, Toxosoutos, 2005, 2, pp. 189-204. 
los lectores conscientes de la extensión de la saga celebrando su unidad y serialidad; también les hace conscientes de cuántas entregas faltan para componerla entera. Por tanto, el resumen no se dirige solamente a revitalizar la memoria de los lectores olvidadizos, sino que ejerce también un papel publicitario de información editorial y actúa como una estrategia de marketing para inducir a comprar toda la saga.

La celebración de los héroes de papel en los templos de la memoria de los libros de caballerías participa sin duda del mismo clima de exaltación de la memoria renacentista, y se explica mejor sobreponiéndole otros ejemplos de la realidad, todos conectados con el arte de la memoria y la conmemoración monumental de poetas, caballeros aristocráticos y hombres de cultura.

Para terminar, quiero recordar brevemente unos pocos ejemplos de arquitecturas reales: el proyecto de Anton Francesco Doni para Arquà Petrarca, el Teatro Olímpico de Vicenza y el museo de Paolo Giovio en Como, todos de hacia 1560. El Teatro de la fama de Anton Francesco Doni, secretario de la Academia Pellegrina de Venecia, fue un proyecto destinado a la ciudad de Arquà, donde vivió Petrarca, un lugar tópico de la memoria literaria: la idea era la de construir un templo para el sepulcro del poeta, rodeado de las estatuas talladas en mármol de varios escritores italianos (Dante, Boccaccio, Ariosto) ${ }^{19}$. La obra no llegó a realizarse, pero Doni siguió describiendo sus "invenciones" y publicó en 1564 Le pitture, un libro de écfrasis donde describe un anfiteatro de cuarenta y dos escalones, cada uno asociado a una figura moral o una virtud como imágenes del arte de la memoria (el Tiempo, la Nobleza, la Gloria, la Fortuna, la Religión). Al final, el Templo de la Fama de Arquà fue retomado parcialmente en la villa Este de Tivoli, donde Federico Zuccari pintó las figuras de Doni en homenaje al cardenal.

Este concepto de teatro que ya vimos en la primera lectura del Palmerín de Roseo viene evidentemente de la influencia del Teatro de la memoria de Giulio Camillo Delminio, amigo de Doni; algo parecido vemos en otro edificio fundamental, este sí realizado y conservado, el Teatro Olímpico del arquitecto Andrea Palladio, encargado por la Academia Olímpica de Vicenza en los mismos años. Verdadero ejemplo de renovación de la ar-

19 Véase Lina Bolzoni, op. cit., pp. 203-209. 
quitectura clásica a imitación de Vitruvio, lo decoran las estatuas de los académicos, en hábito de antiguos romanos en honor de Carlos V, siendo la ciudad de Vicenza de parte imperial (Fig. 4) ${ }^{20}$.

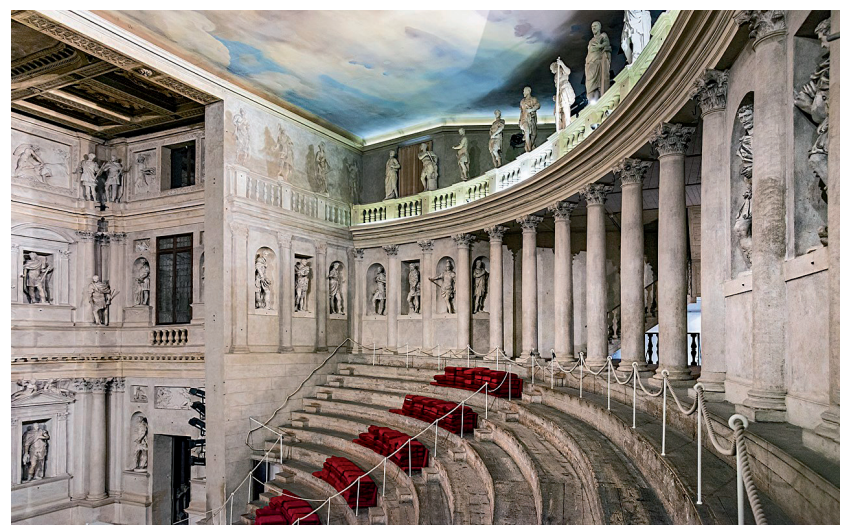

Fig. 4. Teatro Olimpico (Vicenza)

Por último, el gusto para las galerías de hombres ilustres se concretó en otro proyecto artístico: el Museo de Paolo Giovio cerca del lago de Como, que se construyó antes de 1543, pero se perdió posteriormente. Una casa de placer abierta al público, con jardines y salas decoradas con pinturas, que contenía la galería de retratos de famosos hombres políticos, literatos y militares que Giovio había coleccionado durante toda su vida y descrito en su Dialogo delle imprese militari e amorose $(1555)^{21}$.

Recapitulando, los libros de caballerías, no menos que otros géneros como la épica culta y la novela pastoril, comparten el uso de la representación pictórica y plástica para recordar ideas, episodios o personajes ejemplares, y utilizan el papel mnemotécnico del arte en sintonía con las artes de la memoria y los símbolos del pleno Renacimiento.

En los libros de caballerías, apariciones de héroes en pinturas, esculturas, autómatas o caballeros vivientes pueden tener un papel mnemónico para los personajes y para los lectores, pueden representar un lugar cele-

20 Frances Yates, Arte de la memoria, pp. 158 y 340, considera que influyó en la adaptación mnemotécnica de Giulio Camillo.

21 Doni lo había visitado y escribió dos descripciones, una de ellas burlesca. Véase Lina Bolzoni, op. cit., p. 214. 
brativo de la novela misma o crear unos templos de la memoria intertextual del ciclo y del género, de manera metaficcional, autoconsciente y autopromocional; en contraste con el mundo de la épica, donde se celebra la memoria encomiástica de una dinastía histórica, forman una dinastía literaria fundada en la continuidad del género respecto a otros géneros hermanos o antepasados, cercanos o lejanos.

Hemos visto que la memoria puede activarse en relación con todo un ciclo y a propósito de otros ciclos, lo cual indica conciencia del género; y además, mientras describe una comunidad de héroes, igualmente crea una comunidad de autores y de lectores. Por otra parte, puede realizarse en relación con los héroes de la antigüedad, paganos y cristianos, hecho que induce a la celebración de los modernos, elevados como enanos sobre los hombros de los antiguos gigantes.

Finalmente, la frontera con la realidad extratextual es evidentemente porosa, porque estos motivos remiten no solamente a ejemplos como el cenotafio de Maximiliano de Habsburgo, sino, sobre todo en la segunda mitad del Cinquecento, a una multitud de salas pintadas de palacios aristocráticos, cuyo programa iconográfico celebraba las empresas del propietario que había encargado la obra. Para aducir un solo ejemplo italiano, se puede recordar el espléndido salón de los "Fasti farnesiani" del palacio Farnese de Caprarola ${ }^{22}$.

En conclusión, las pinturas y las esculturas cumplen una función visual (evidentia) mnemónica, didascálica y ejemplar: como en un teatro de la memoria, la función interna para los personajes espectadores es principalmente la de celebrar a los héroes y conservar su recuerdo para la incitación a nuevas empresas. Para el lector extradiegético, igualmente, funcionan como un mecanismo de recapitulación del argumento de las novelas anteriores, que ofrece a un solo golpe de vista el contenido de millares de páginas. Además, para el autor, estas figuras fijan en una sucesión jerárquica el lugar que él mismo se atribuye en la tradición y, consiguientemente, representa una ocasión de auto-celebración literaria. Al exaltar

22 Eugenio Battisti, Cicli pittorici: storie profane, Milano, Touring club italiano, 1981. Julian Kliemann, Gesta dipinte: la grande decorazione nelle dimore italiane dal Quattrocento al Seicento, [Milano], Silvana, 1993; "Cicli di affreschi a soggetto storico nel Cinquecento", en Arte Lombarda, 2-3-4 (1995), pp. 103-109; Giuseppe Pavanello e Vincenzo Mancini, Gli affreschi nelle ville venete. Il Cinquecento, Venezia, Marsilio, 2009. 
en la pintura y en la escultura a los paladines anteriores, los autores de los libros de caballerías confieren a posteriori un estatuto de nobleza literaria a sus héroes que culmina un recorrido de siglos, reclamando así la subordinación de todo el mundo caballeresco a su singular proyecto narrativo. 